\title{
ADVANCES IN CROP RESPONSES TO ENHANCED UV-B RADIATION
}

\author{
LI, Y. S. ${ }^{1}-$ LIU, X. B. ${ }^{1 *}-$ HENSON J. F. ${ }^{2}$ \\ ${ }^{1}$ Key Laboratory of Mollisols Agroecology, Northeast Institute of Geography and Agroecology, \\ Chinese Academy of Sciences, 138 Haping Road, Harbin, 150081, China \\ (phone: +86-451-86691167) \\ ${ }^{2}$ Southern University Agricultural Research and Extension Center, Baton Rouge, LA 70813, USA \\ *Corresponding author \\ e-mail: liuxb@iga.ac.cn \\ (Received $23^{\text {rd }}$ Nov 2015; accepted $25^{\text {th }}$ Apr 2016)
}

\begin{abstract}
The increased ultraviolet-B (UV-B) radiation (280-320 nm) on the Earth's surface is one of the most important concerns of global change. This concern is primarily because increased UV-B radiation has been unambiguously shown to be responsible for the majority of harmful effects on aquatic as well as terrestrial organisms, and thus influence ecological interactions. For the past 4 plus decades, many studies have been conducted on the damaging effects of elevated UV-B radiation on plants. These studies have shown a diverse range of responses to UV-B radiation, and might be in general arbitrarily divided into two classes, photomorphogenic and stress responses at the morphological, physiological, biochemical and molecular levels. Crop plants evolved different adaptive or defensive mechanisms to UV-B radiation, including accumulation of UV-absorbing sunscreens, production of enzymatic and non-enzymatic antioxidants, changes of phytohormones or activation of DNA-repairing enzymes. A diagram illustrating the general responses of UV-B radiation and complexity of the interactions among factors was developed. Three urgent specific researches are proposed, which might provide opportunities for genetic engineering and possibility of breeding to deal with potential crop yield reductions due to elevated UV-B in agricultural systems, and thus will play a major role in determining the crops future.
\end{abstract}

Keywords: global change, UV-absorbing compounds, antioxidants, phytohormones, DNA-repair

\section{Introduction}

There has been significant interest in documenting the potential impacts of long-term increases in ultraviolet-B (UV-B, 280-320 nm) radiation on crop plants over the last several decades (Germ et al., 2006; Caldwell et al., 2007; Ballaré et al., 2011; Häder et al., 2011; Liu et al., 2013). Great intraspecific variation in the responses of plants to UV-B radiation has been observed in main crops, e.g., wheat (Li et al., 2010; $\mathrm{Zu}$ et al., 2010; Singh et al., 2012; Schreiner et al., 2012), maize (Biggs and Kossuth, 1978; Correia et al., 1999; Cartwright et al., 2001), soybean (Sullivan and Teramura, 1990; D'surney et al., 1993; Caldwell et al.,1994; Feng et al., 2001; Li et al., 2002; Zu et al., 2003; Baroniya et al., 2013), rice (Barnes et al., 1990; Dai et al., 1994; Kumagai et al., 2001; Hidema and Kumagai, 2006) and sorghum (Ambasht and Agrawal, 1998; Kataria and Guruprasad, 2012a). There has been significant interest in documenting the potential impacts of long-term increases in ultraviolet-B (UV-B, 280-320 nm) radiation on crop plants over 
the last several decades (Germ et al., 2006; Caldwell et al., 2007; Ballaré et al., 2011; Häder et al., 2011; Liu et al., 2013).

Direct effects of natural or enhanced levels of UV-B radiation on plant yield have been detected under field conditions. However, in quantitative terms, these effects tend to be modest, with growth reductions rarely exceeding 20\% (Searles et al., 2001; Newsham and Robinson, 2009; Wargent et al., 2009; Ballaré et al., 2011). These differences in UV-B sensitivity among crops and cultivars can be due to different adaptive or defensive mechanisms to UV-B radiation, which provides opportunities for genetic engineering and possibility of breeding to deal with potential crop yield reductions due to elevated UV-B in agricultural systems, and thus will play a major role in determining the crops future.

Relative to the 1979-1992 conditions, for the 2010-2020 time period, the GISS model results indicate a springtime enhancement of erythemal UV doses of up to $14 \%$ in the Northern hemisphere and $40 \%$ in the Southern hemisphere (Taalas et al., 2000). Therefore, the discovery of how crop plants interact with UV-B radiation, and what kind of protective strategies or mechanisms they possess in order to cope with the harmful UVB radiation, is essential to a better understanding of the balance between damage and protection.

Earlier review on field crop responses to UV-B reported the effects of UV-B radiation on visual symptoms, cell and its components, leaf ultrastructure and anatomy, photosynthesis, growth and development, transpiration and stomatal conductance, production and yield, as well as interactions of UV-B with abiotic and biotic factors of crop plants such as low temperature and drought (Kakani et al., 2003; Breznik et al., 2009). This article summarized much-needed and useful information to researchers regarding the general consequences of ultraviolet-B radiation on crop plants from the morphological, physiological, especially biochemical, cellular and molecular levels, and intended to raise genetic modification questions for molecular biologists and geneticists to address, which will aid future climate negotiations and support growers to maintain high productivity.

\section{Leaf morphology, anatomy and $U V$-absorbing compounds}

Photomorphogenic responses result in altered architecture or chemical composition and may be thought to be adaptive responses of plants to the incident radiation micro-climate, which may ultimately modify the penetration of UV radiation into plants (Beggs and Wellman, 1994; Ballaré et al., 1992, 2011). UV-induced morphological changes include thicker leaves, shorter petioles, shorter stems, increased axillary branching and altered root: shoot ratios (Robson et al., 2015). The epidermal attenuation appears to be the dominant UV-B screening mechanism in the majority of plants. In order for UV radiation to be effective in plants, it must effectively penetrate into the tissues and be absorbed. Ultraviolet penetration varies with plant species. Penetration of UV-B was found to be the greatest in herbaceous dicotyledons (broad-leaf plants) and was progressively less in woody dicotyledons, grasses and conifers (Day et al., 1992, 1993). 
Enhanced UV-B reduced leaf area and leaf thickness (indicated by specific leaf weight) has been reported in maize, Amaranthus tricolor and sorghum varieties (Correia et al., 1999; Kataria and Guruprasad, 2012), while specific leaf area and length of internodes and petiole in Indian cress (Tropaeolum majus) were unaffected by enhanced UV-B radiation (Germ et al., 2015). The decrease in leaf thickness may have increased the UV-B penetration within leaves and decreased photosynthetic rates and dry weight accumulation. Increased epidermal cell wall thickness was also found in loblolly pine (Pinus taeda) and Scots pine (Laakso et al., 2000). Qi et al. (2003) found that there was a good correlation between total leaf thickness and total concentration of leaf UV-B absorbing compounds in southern broadleaf tree species in USA, and a strong presence of UV-absorbing compounds in the upper and lower epidermis, the vascular bundles and the leaf hairs, if present. However, the main site of UV-B attenuation took place within the upper leaf epidermis (Qi et al., 2003).

The accumulation of flavonoids in the epidermis has been shown to reduce epidermal transmittance of UV-B radiation (Tevini et al., 1991), and those exhibited high epidermal transmittance may be less UV-B tolerant. Feng et al. (2003) found that the greater tolerance of soybean cultivar 'Jindou' to elevated UV-B exposures was attributed partly to its higher foliar flavonoid content, smaller leaf size, thicker leaf cuticle and scabrous (hairy) lamina. Differences in UV-absorption characteristics between a barley (Hordeum vulgare) mutant and the mother line indicated that the flavonoid mutant exhibits increased sensitivity to UV-B radiation, though the content of flavonoid in the mutant was only 7\% compared to the mother variety in the primary leaf (Reuber et al., 1996). In addition, cuticular waxes and lignins may also serve protective roles by absorbing UV radiation (Caldwell et al., 1983). Wax content increased in tolerant genotypes while it decreased in the susceptible genotypes, because wax layer is an important surface character that responds to UV-B radiation (Kakani et al., 2004).

UV-B radiation is an important environmental factor for many plants with remarkable influence on defence-related secondary metabolite biosynthesis (Germ et al., 2015). Many studies suggest that the accumulation of UV-absorbing phenylpropanoid compounds, mainly flavonoids, anthocyanins and related phenolics in cell vacuoles and/or cell walls of the leaf epidermis is a protective measure against UV-B effects on mesophyll tissue of a leaf (Robberecht and Caldwell, 1978; Schmelzer et al., 1988; Day, 1993; Li et al., 1993; Beggs and Wellman, 1994; Rozema et al., 1997; Hutzler et al., 1998; Bornman, 1999; Mazza et al., 2000; Bieza and Lois, 2001; Flint et al., 2004; Sullivan et al., 2007; Izaguirre et al., 2007). In fact, in a meta-analysis, Searles et al. (2001) found that an increase in UV-absorbing compounds in response to supplemental UV-B was the most consistently reported response to UV-B radiation. UV-B absorbing compounds are present throughout the leaf, but accumulate significantly in leaf trichomes and epidermal cells (Zancan et al., 2008). They have effective radical scavenging capabilities, and can contribute directly to enhance photoprotection against UV-B radiation (Smith and Markham, 1998; Karioti et al., 2008; Li et al., 2012).

Arabidopsis flavonoid mutants are hypersensitive to UV-B radiation, thus confirming the role of flavonoids and other phenolic compounds in the UV-B protection of plants ( $\mathrm{Li}$ 
et al., 1993). In addition, another Arabidopsis mutant reported to be tolerant to lethal UV-B levels showed constitutively elevated accumulation of flavonoids and other phenolic compounds (Bieza and Lois, 2001). Flavonoids not only served as UV-B filters, but also were hypothesized to act as antioxidants, by absorbing UV-B radiation in the upper tissue layer and thus preventing damage to sensitive targets, their absence could lead to greater oxidative stress (Peng et al., 2003). Changes in flavonoid contents in wheat leaves have been observed under field conditions (Li et al., 2000). In soybean, increases in total leaf phenolics exposed to ambient UV radiation were demonstrated by Mazza et al. (2000).

Levizou and Manetas (2002) showed significant correlations between total phenolic levels and UV-B absorbing capacity (simple methanolic absorbance at $300 \mathrm{~nm}$ ). Enhanced UV-B radiation induced increased synthesis of total phenolic compounds in leaves, but not in flowers of Indian cress (Tropaeolum majus) (Germ et al., 2015). Koti et al. (2007) observed genotypic variation in the production of these compounds at high UV-B levels. However, opposite results were reported by different authors. Kreft et al. (2002) showed that exposure of buckwheat plants (Fagopyrum esculentum Moench) to elevated UV-B radiation reduced the accumulation of rutin, a flavonoid with antioxidant properties. Yao et al. (2006) found that effect of UV-B radiation on the concentration of the flavonoid rutin in buckwheat leaves depended on leaf position and the level of UV-B radiation. Rutin concentration was higher in top leaves than in lower ones regardless of the UV-B level, top leaves typically receive more radiation than lower leaves. Sullivan et al. (2007) did not find that even though UV-B absorbing compounds accumulated with an imposed stress, but these compounds were not directly related to sensitivity/tolerance of soybean genotypes.

Intraspecific differences in the composition and concentration of flavonoids have been found among five cultivars of Cucumis sativus (Murali and Teramura, 1986) and in two cultivars of soybean (Murali et al., 1988), 20 cultivars of wheat (Li et al., 2000), 10 soybean cultivars (Feng et al., 2001), and 20 soybean cultivars (Li et al., 2002). Screening of the total flavonoid contents in 20 Chinese soybean cultivars in a field study using UV-B lamps revealed that seven cultivars had increased total flavonoid levels while five showed decreased levels, and no changes were observed in eight cultivars ( $\mathrm{Zu}$ et al., 2003). Since alterations in the levels of individual flavonoids were not taken into account, UV-B could have had an impact on certain compounds without increasing the total level. Warren et al. (2003) found that certain flavonoids were selectively produced after UV-B exposure.

A series of experiments provided convincing evidence that plants subjected to UV-B radiation responded to changes in the content and ratios of different flavonoid in leaf epidermal cells, wax, and hairs (Harborne and Williams, 2000). Some flavonoid increased much more than others, especially the flavonoids with ortho-hydroxy structures in B-ring such as quercetin and quercetin glycoside in Trifolium repens (Hofmann et al., 2000), luteolin in Marchantia polymorpha (Markham et al., 1998), chlorogenic acid in Cucumis sativus (Kondo and Kawashima, 2000), isoorientin acylated glucosides in Oryza sativa (Markham et al., 1998). 
Winter and Rostas (2008) confirmed that three of the analyzed flavonoids showed a significant increase in plants receiving full ambient radiation. Of these, two compounds were quercetin based flavonols, resulting in a shift in the relative flavonol content in favor of the quercetin glycosides and at the expense of kaempferol glycosides. As quercetin flavonols are known to have an improved ability as free radical scavengers due to the additional ortho-dihydroxyl group in the B-ring (Harborne and Williams, 2000) compared to kaempferol flavonols, it might be of advantage for the plants to invest more in quercetin flavonols under UV stress. Due to our lack in understanding of flavonoid function in plants, further studies would be worthwhile. Laboratory studies have demonstrated that the regulation of flavonoid biosynthesis may involve multiple photoreceptors, including the phytochromes, blue-absorbing photoreceptors, and one or more UV photoreceptors (Beggs and Wellmann, 1994).

Genetic blocks in the synthesis of phenolic sunscreens in phenylpropanoid mutants are known to result in increased susceptibility to UV (e.g. Li et al., 1993; Lois and Buchanan, 1994; Stapleton and Walbot, 1994; Landry et al., 1995; Reuber et al., 1996), however, it is not yet clear whether the slight variations in levels of UV-absorbing compounds that are commonly detected among varieties of the same species or between plants subjected to different UV regimes are physiologically significant under field conditions.

The accumulation of anthocyanins in the vacuoles of epidermal cells where they attenuate the UV component of sunlight with minimal absorption of photosynthetically active radiation has also been suggested (Stapleton and Walbot, 1994; Landry et al., 1995). Gould et al. (2002) reported that purified anthocyanin extracts showed strong antioxidant properties in vitro, and they can also scavenge reactive oxygen in living cells. By real-time imaging of $\mathrm{H} 2 \mathrm{O} 2$ in cells after mechanical injury, they found that anthocyanins, among various flavonoids, were the only molecules suitably located to account for the enhanced rates of $\mathrm{H} 2 \mathrm{O} 2$ scavenging, suggesting that anthocyanins have elevated antioxidant capabilities in vivo (Gould et al., 2002). Therefore, the mechanism by which anthocyanins confer UV protection may involve UV absorption or scavenging of reactive oxygen species (ROS), or both. In Arabidopsis thaliana, sinapate esters also provide UV-B attenuation, but this biosynthetic pathway is not present in corn (Zea mays) (Sheahan, 1996).

Proline is regarded as an osmoprotectant, however, several authors implicated a role for proline in the detoxification of ROS (Saradhi et al., 1995; Matysik et al., 2002), and an enhanced accumulation of proline in soybean leaves could be linked with detoxification against Ni and UV-B induced oxidative stress (Prasad et al., 2005).

A similar manner as ascorbate or glutathione and function as an electron donor for the peroxidase reaction was assumed (Takahama and Oniki, 2000). A key function of ascorbic acid in the apoplast is redox buffering, which protects the plasmalemma from oxidative damage. It has been demonstrated that the symplastic ascorbate redox state is relatively constant throughout the life of a cell, despite large changes in apoplastic ascorbate. Moreover, the ascorbate redox state in the apoplast is largely independent of that in the symplasm and the ascorbate pool in the apoplast is flexible. This flexibility 
allows the cell to sense the environment and contribute to trigger molecular responses (Pignocchi and Foyer, 2003).

Due to our lack in understanding of functional significance of natural variations in phenylpropanoid levels, there is a knowledge gap regarding the photocontrol of phenylpropanoid accumulation under field conditions, and the dynamics of specific compound accumulation, localization patterns and constitutive or background levels of UV-screening compounds warrant further studies.

Besides the compounds mentioned above, recently, Smrkolj et al. (2006) proposed that selenium (Se) could protect plants from the harmful effects of UV-B radiation. They observed that enhanced UV-B radiation leads to higher selenium accumulation in flowers compared to ambient UV-B radiation conditions in buckwheat. Germ et al. (2009) found that for St. John's wort (Hypericum perforatum L.) herb, the highest concentration of Se was found in plants exposed to reduced UV-B radiation, which might be a self-denfence mechanism involved in this plant for antioxidative effects. Therefore, Selenium can increase the tolerance of plants to UV-induced oxidative stress, and there could be a similar connection between radiation and selenium as that known for flavonoids and radiation.

\section{The antioxidant defense system}

To keep UV-B damage to a minimum, plants possess enzymatic and non-enzymatic antioxidative defense systems in cellular compartments (Bowler et al., 1992). UV-B exposure is known to lead to the generation of active oxygen species (AOS) and eventually results in oxidative stress in plants (Arnott and Murphy, 1991; Dai et al., 1997; Hideg et al., 2003; Kalbina and Strid, 2006). AOS not only function as destructive radicals, but also as signaling molecules during UV-B responses (Green and Fluhr, 1995; Mackerness et al., 1997, 2001; Mackerness and Jordan, 1999).

The inhibition effect on plant growth and development was mainly due to enhanced oxidative stress caused by UV radiation (Jansen et al., 1998). It has also been reported that UV-B can promote the formation of lipid oxidation products, destroy the natural lipid soluble antioxidants (Salmon et al., 1990), and induce the expression of the genes which encode for antioxidants (Strid et al., 1994).

It has already been demonstrated that plant cells and tissues protect themselves against oxidative insults through the up-regulation of a wide variety of antioxidants enzymes to UV-B exposure (Davies, 1986; Beligni and Lamattina, 1999; Chen et al., 2003). The main enzymatic antioxidant defense system includes enzymes such as superoxide dismutase (SOD; EC 1.15.1.1), catalase (CAT; EC 1.11.1.6), guaiacol peroxidase (POD; EC 1.11.1.7), ascorbate peroxidase (APX; EC1.11.1.11), glutathione reductase (GR; EC1.6.4.2), and dehydroascorbate reductase (DHAR; EC1.8.5.1) (Bowler et al., 1994; Kondo and Kawashima, 2000).

SOD rapidly converts $\mathrm{O}_{2}$ to $\mathrm{H}_{2} \mathrm{O}_{2}$ which can then be converted to water and oxygen by CAT (Noctor and Foyer, 1998). Contrasting responses of SOD to UV-B exposure have been reported revealing no uniform responses. For example, SOD activity was increased 
by UV-B radiation in pea and wheat (Alexieva et al., 2001), Arabidopsis (Rao and Ormord 1995), Lemna gibba (Babu et al., 2003) and rice (Dai et al., 1997), but was not affected in barley (Mazza et al., 1999) and soybean (Malanga et al., 1999), and was decreased in sunflower cotyledon (Costa et al., 2002).

Also, SOD expression was not affected by UV-B radiation in Nicotiana plumbaginifolia L. (Willekens et al., 1994), but was decreased in Pisum sativum (Strid et al., 1994). In a field study, supplemental UV-B increased SOD activity in wheat and mung bean (Agrawal and Rathore, 2007).

CAT is a constitutive component of peroxisomes and has a low substrate affinity (Corpas et al., 1999). An alternative mode of $\mathrm{H}_{2} \mathrm{O}_{2}$ destruction is via APX which is found throughout the cell (Jimenez et al., 1997). APX is a specific peroxidase that catalyzes the breakdown of $\mathrm{H}_{2} \mathrm{O}_{2}$ at the expense of oxidizing ascorbate to monodehydroascorbate. APX isozymes are distributed in at least four cells compartments: the stroma, the thylakoid membrane, the microbody, and the cytosol (Asada, 1992). The removal of $\mathrm{H}_{2} \mathrm{O}_{2}$ through series of reactions is known as the ascorbate-glutathione cycle (Noctor and Foyer, 1998).

Synthesis of antioxidant enzymes like POD, APX and SOD have been observed in UV-B treated Arabidopsis thaliana seedlings (Rao et al., 1996). Liu and McClure (1995) revealed that POD enzyme activities were increased under UV-B irradiation to adapt to the oxidative stress, and the SOD activities were changed differently according to the UV-B irradiation intensities (Tekchandani and Guruprasad, 1998).

Although it is not known how plants irradiated with UV-B generate AOS, it is thought that NADPH oxidase may be involved in the generation of AOS (Rao et al., 1996). Direct evidence of induction of NADP-malic enzyme by UV-B radiation was observed in leaves, stems and roots of three bean cultivars (Pinto et al., 2002). These results suggest that NADP-malic enzymes play an active role in plant defense responses against UV-B, possibly by providing NADPH for lignin and flavonoid biosynthesis. It is also possible that measures of only total activities of enzymes may not adequately reflect $\mathrm{UV}$-induced compartment-specific changes or enzyme alterations that do not change total activity. For example, UV-B could differently regulate enzyme isoforms as reported for POD (Murali et al., 1988), CAT (Willekens et al., 1994), SOD (Babu et al., 2003; Rao et al., 1996) and APX (Yannarelli et al., 2006a) in previous studies. More studies are needed to resolve these issues.

Logemann et al. (1995) found UV-induction of enzymes can provide carbon substrates for the shikimate pathway, while Casati and Walbot (2003) proposed that induction of enzymes that can also provide energy in the form of ATP for the synthesis of these and other molecules necessary for cell functions under UV-B stress. Shweta and Agrawal (2006) have shown that simultaneous exposure of UV-B+Cd and UV-B+Ni caused increased accumulation of malondiadehyde (MDA) content in spinach. Increased MDA content caused by UV-B indicated a loss of membrane function and induction of oxidative damage ( $\mathrm{Li}$ et al., 2012). Elevated MDA content is regarded as a sensitive indicator of oxidative stress in plants exposed to different stresses including $\mathrm{Cd}$ and UV-B (Wang et al., 2008). 
A hierarchical cluster analysis by $\mathrm{Zu}$ et al. (2003) indicated that the contribution of each physiological indicator (\% change) to the overall sensitivity of soybean cultivars to enhanced UV-B radiation had the following sequence: SOD activity, membrane permeability, flavonoid contents, malonaldehyde (MDA) contents, chlorophyll a contents, chlorophyll b contents. Zu et al. (2010) further demonstrated that UV-B induced oxidative stress via indirect mechanisms such as inhibition of antioxidative defense systems, or via the activation of ROS-producing enzymes such as NADPH oxidases.

Studies on the effects of UV-B on the enzymatic antioxidants at both the activity level (Agrawal and Rathore, 2007; Yannarelli et al., 2006b) and the mRNA level (Willekens et al., 1994) have yielded inconsistent results so it is not clear how uniform this response is among plant species and how this may be modified by concurrent environmental conditions. Yannarelli et al. (2006b) demonstrated that increased $\mathrm{HO}^{-}$activity was associated with augmented protein expression and transcript levels.

The non-enzymatic defense system consists of low molecular weight antioxidants such as proline, ascorbate, glutathione, $\alpha$-tocopherol, and carotenoids (Larson, 1988; Rao et al., 1996; Arora et al., 2002; Matysik et al., 2002; Giordano et al., 2004; Jain et al., 2004; Shiu and Lee, 2005). Ascorbic acid (AsA) is a major primary antioxidant reacting directly with hydroxyl radicals, superoxide and singlet oxygen, and also a powerful secondary antioxidant reducing the oxidized form of $\alpha$-tocopherol. Increases in the AsA pool in response to UV-B exposure have been observed in several species (Galatro et al., 2001; Dai et al., 1997; Takeuchi et al., 1996; Rao and Ormord, 1995). However, in maize seedling, UV-B exposure had no effect on the AsA content (Carletti et al., 2003). Glutathione is the major low molecular weight thiol compound in most plants (Foyer et al., 1994). Overall, glutathione (or homoglutathione) appears to play a role in protection against oxidative damage arising from a number of stresses such as irradiation, heat, and exposure to heavy metals (Grill et al., 1985). Moreover, ascorbic acid and glutathione may be involved in several types of protective mechanisms (Wefers and Sies, 1988). The reduced and oxidized forms of ascorbate and glutathione are transported across the chloroplast envelope (Anderson et al., 1983; Beck et al., 1983) by transporters whose activity may be changed in response to stress.

Ultraviolet radiation has been shown to be very effective in inducing lipid oxidation of biological membranes (Kochevar, 1990; Foyer et al., 1994), polyunsaturated fatty acids (Yamashoji et al., 1979) and phospholipid liposomes (Pelle et al., 1990). There is a considerable amount of data that demonstrates ways in which UV radiation alters membrane structure or function: changes in membrane permeability, inhibited K-ATPase and peroxidized lipids in wheat (Triticum aestivum) (Li et al., 2000; Wright et al., 1981) and decreased membrane resistance in Chara coralline (Doughty and Hope, 1973). The damage to nonphotosynthetic membranes that are detected by electron microscopy generally requires high fluence or occurs only after a long lag time following irradiation. In the latter case, the effect of UV can be regarded as an acceleration of normal senescence processes (Skokut et al., 1977). The physiological effects of UV stimulated membrane changes are uncertain. There is little evidence that the UV damage to 
membranes is responsible for cell death. UV stimulated membrane changes may play a role in the UV-induced synthesis of anthocyanins (Murphy, 1983).

Hydrogen peroxide is known to diffuse across biological membranes and causes cellular damage. An increase in lipid peroxidation and $\mathrm{H}_{2} \mathrm{O}_{2}$ was demonstrated following UV-B treatments (Mishra et al., 2011). Understanding the mechanisms for removal of AOS is important for UV studies because increasing evidence suggests that AOS are involved in the damage caused by UV-B radiation. For example, UV-B radiation has been shown to increase AOS levels (Kalbina and Strid 2006; Hideg et al., 2003) and lipid peroxidation (Yannarelli et al., 2006b; Yang et al., 2005) in plants.

Therefore, adaptation or acclimation to photooxidative stress is multifactorial and many factors are involved in the overall defense strategy of the plant. A more indepth understanding of the generation and scavenging of AOS is needed before this relationship can be fully understood. However, very few studies have been conducted on the impacts of solar UV-B radiation on enzymes and antioxidants under natural and UV-B exclusion conditions (Mazza et al., 1999; Agrawal and Rathore 2007; Xu et al., 2008a).

\section{Phytohormones responses to $U V-B$}

It is well known that phytohormones play a vital role in the regulation of the growth and development of higher plants, as they are involved in controlling the ongoing process in the cell division, elongation and development, morphogenesis, and biological production (Beffa et al., 1990; Liu et al., 2010). The importance of the five "classical" classes of phytohormones in higher plants is well established. More recently, several other molecules have also been recognized as phytohormones. These include jasmonic acid (JA), salicylic acid (SA), brasinosteroids (BR) and polyamines (PA) (Saruhan et al., 2012).

The synthesis and action of phytohormones are modulated by environmental factors (Lachno and Baker, 1986). Plant hormones are the initiation factor of adversity-responsive gene expression (Zaffari et al. 1998). Studies indicated that a relatively small increase in UV-B can have dramatic effects on synthesis, transport, and allocation of plant endogenous hormones such as indole-3-acetic acid (IAA), cytokinin (CTK), and abscisic acid (ABA) etc., which resulted in inhibition of cell elongation, stomatal closure, and decreasing photosynthetic rate (Keiller and Holmes, 2001).

Photooxidation free-radical damage caused by strengthening UV-B radiation decreased IAA and gibberellins (GA) content, but increased indole acetic acid oxidase (IAAO) activity, which reinforced the harm from free radical induced by UV-B stress (Huang et al., 1997; Wang and Li, 2000; Huang et al., 2005).

Reduction in plant height has often been used as an index to assess the degree of UV-B radiation sensitivity (Biggs and Kossuth, 1978). UV-B radiation significantly dwarfed soybean, primarily due to shorter internodes rather than smaller node number (Teramura, 1980). This could be due to photo-oxidative destruction of the phytohormone IAA followed by reduced cell wall extensibility as demonstrated in sunflower seedlings (Ros and Tevini, 1995). The levels of ethylene, which promote radial growth and reduce 
elongation, are increased after irradiation with UV-B (Caldwell et al., 1995). However, the mechanism for UV-B radiation to increase plant height is still not clear. UV-B radiation may directly affect cell division and some intrinsic growth characteristics (Beggs et al., 1985).

It is believed that GA signaling is essential for internode elongation, cambial activity, and fiber differentiation, which has been documented in tobacco stems (Dayan et al., 2012). Phytochromes regulate GA synthesis during germination and seedling establishment. However, in the UV region of the spectrum, the absorption spectra for Pr and Pfr exhibit little discrimination (Lagarias et al., 1987; Chen et al., 2004) so this family of photoreceptors may not be involved in controlling soybean internode elongation.

Luo et al. (2006) and Zhu et al. (2006) demonstrated that several GA hormones were present in high concentrations in the upper-most internode of a mutant rice plant and were involved in the elongation of this internode. Also Sharma and Guruprasad (2009) demonstrated similarities in response of young Amaranthus caudatus plants to exclusion of UV-B and exclusion of both UV-A and UV-B with responses to external application of GA3, including increased hypocotyl lengths.

Changes in plant height caused by increases in the internode lengths due to UV-B radiation were likely mediated by a change in the presence of phytohormones or plant growth regulators, but the genetic mechanisms and biochemical syntheses that cause the changes are not known. Several experiments suggest the causal phytohormone is likely to be a GA, judged from the effect of exogenous applied GA upon soybean. Mislevy et al. (1988) applied GA3 to soybean at seedling emergence and found hypocotyl elongation and elongation of the 1 st and 2 nd internodes

Peng and Zhou (2009) using hydroponics culture investigated the effects of La III on the contents of endogenous hormone in soybean seedlings under elevated ultraviolet-B radiation $(280-320 \mathrm{~nm})$. They showed that the content of IAA in soybean seedlings decreased initially and then increased when the seedlings underwent UV-B treatment during the stress and convalescent period, while indole acetic acid oxidase (IAAO) activity increased at first and then decreased. A similar change of ABA content and IAAO content in soybean seedlings occurred; GA content decreased during the experiment compared with control. They also found that the content of IAA and GA in soybean seedlings with La III + UV-B treatment was higher than those of UV-B treatment; IAAO activity and GA content in soybean seedlings with La III + UV-B treatment were lower than those of UV-B treatment.

One function of $\mathrm{ABA}$ is to regulate activity of the stomatal guard cells. In bad conditions, accumulation of $\mathrm{ABA}$ in plant tissue can reduce stomatal conductance, caused stomatal closure, and inhibit photosynthesis. Studies have showed that UV-B leads to stomatal closure or incremented stomatal resistance (Tevini and Teramura, 1989; Bjorn, 1996), which resulted from leakage of K from the guard cell or changes of the stomatal regulated hormone ABA content (Yang et al., 2000).

The process of $\mathrm{ABA}$ induced stomatal closure required $\mathrm{H}_{2} \mathrm{O}_{2}$, and $\mathrm{NO}$ to attend, and the accumulation of ABA content by UV-B radiation originated from increased chloroplast membrane permeability, turgor loss, and disengaged inhibitory action of an 
ABA synthetic (Burnett et al., 2000; Wang et al., 2001). Alonso et al. (2015) found that the triterpene squalene and the diterpene phytol were significantly higher in the treatment with combinations of water deficit, solar UV-B and ABA applications, and two application of ABA on leaves and berries, at veraison and 15 days after, were enough to activate compounds with antioxidant and antifungal properties, and thus proposed it as a possible acclimation mechanism that modifies membrane fluidity under environmental signals both biotic and abiotic.

Salicylic acid (SA) is considered to be an important signalling molecule, which plays an important role in regulating a number of physiological processes and plant resistances to stresses (Saruhan et al., 2012). Studies have demonstrated that SA can ameliorate the injurious effects of abiotic stresses on crops (Nazar et al., 2011; Bandurska and Cieślak 2013). Belkhadi et al. (2010) found that SA pre-soaking counteracted Chl destruction, and the foliar application of SA proved to be equally fruitful in increasing the pigment content (Hayat et al., 2005).

Plants accumulate large amounts of SA when exposed to UV radiation and SA is thought to be directly involved in signalling various antioxidant responses (Larkindale and Knight 2002; Bandurska and Cieślak 2013). Several reports show that SA can induce antioxidant activity under multiple stresses (Mutlu et al., 2009; Saruhan et al., 2012). A decline in activities of CAT, POD, and SOD was observed in plants treated with SA (Choudhury and Panda, 2004).

Li et al. (2014) showed that SA alleviated the adverse effects of Cd and/or UV-B on growth, and pigment content, but did not mitigate the inhibitory effect of $\mathrm{Cd}$ on chlorophyll fluorescence parameters in soybean seedlings. Cd and/or UV-B induced oxidative stress and increased lipid peroxidation that was significantly decreased by SA pre-treatment. They also showed that the Cd and/or UV-B increased SOD activity, decreased POD activity, and CAT activity was mostly unaltered. They thus proposed that SA might act as one of the potential antioxidants as well as a stabilizer of membrane integrity to improve plant resistance to the Cd and/or UV-B stress. Ervin et al. (2004) found that exogenous SA application alleviated the damaging effects induced by UV-B radiation in Kentucky bluegrass. SA stimulates photosynthetic machinery by increasing the content of chlorophyll in UV-stressed plants (Mahdavian et al., 2008). Stratmann (2003) reported that UV radiation may influence JA levels and lead to an overlap in gene expression caused by UV-B and herbivory.

However, the mechanism of plant hormones including SA- and JA-induced resistance to $\mathrm{UV}-\mathrm{B}$ radiation is still unclear.

\section{DNA damage and genetic consequences}

Because of its absorption spectrum, DNA is a major target of UV-B damage; even low doses of radiation can kill mutants lacking specific DNA repair pathways (Britt et al., 1993; Britt, 1996; Landry et al., 1997). UV-B radiation is reported to cause cellular damage by generating photoproducts in DNA and direct damage to proteins (Gerhardt et al., 1999; McNamara and Hill, 2000; Bray and West, 2005). 
A variety of DNA damage caused by UV radiation is due to direct absorption of UV-B radiation by the native DNA molecule or indirectly by oxidative stress via free radicals and reactive oxygen species (ROS) (Latifi et al., 2009). Hargreaves et al. (2007) proposed that UV-A radiation that is not directly absorbed by DNA, can still induce DNA damage either by producing a secondary photoreaction of existing DNA photoproducts or via indirect photosensitizing reactions. The measurements of DNA damage by Mazza et al. (2000) showed that the UV-B component of sunlight induced greater perturbations in the cells of those leaves that scored as more UV transparent in the fluorescence determinations. They also determined that, under field conditions, most of the sunscreen response induced by solar UV in soybean can be attributed to the UV-B component.

Repair mechanism of plants includes repair of DNA damages by excision repair or by repair of pyrimidine dimers as photolyase, activated by UV-A and photosynthetically active radiation (Britt, 1996; Taylor et al., 1997). Absorption of UV-B radiation by DNA causes phototransformations resulting in the production of cyclobutane pyrimidine dimers (CPDs) and pyrimidine (6-4) pyrimidona dimers (6-4 PPs). Because DNA and RNA polymerases are not able to read through these photoproducts, their elimination by CPD photolyases is essential for DNA replication and transcription (Britt and May, 2003).

It is well-documented that elevated UV-B radiation causes an up-regulation of genes and enzymes involved in the phenylpropanoid pathway (Chappell and Hahlbrock, 1984; Rozema et al., 1997; Ryan et al., 2002). Chalcone synthase (CHS; EC 2.3.1.74) catalyzes the first step reaction of the flavonoid biosynthesis, it may be possible to increase the production of UV-B-protective flavonoids by genetically improving the expression of CHS. Soybean CHS is encoded by a multigene family (GmCHS) of at least eight members (GmCHS1-GmCHS8) (Akada and Dube, 1995). Shimizu et al., (2000) reported that the expression of every member of the family was induced by exposure to white light and was enhanced further by supplemental UV-B radiation, except for that of GmCHS2. It has been shown that under realistic UV-B conditions, reduction in Rubisco levels is the primary cause for the decline in photosynthetic rate (Allen et al., 1997; Baker et al., 1997). Similarly, reduction in the expression and synthesis of Lhcb, encoding the harvesting complex proteins, and psbA, encoding the D1 polypeptide of PSII, could have potential impacts on the efficiency of the photosynthetic system (Jordan et al., 1998; Mackerness et al., 1997). Photosynthetic genes may be down-regulated (Surplus et al., 1998; Mackerness et al., 2001; Jordan, 2002).

Casati and Walbot (2003) examined the response of gene expression in maize to solar UV-B under field conditions, and found several photosynthesis-associated genes were decreased and antioxidant-associated genes were increased. Also, the genes involved in fatty acid metabolism and oxylipin biosynthesis were increased by solar UV-B (Izaguirre et al., 2003). Using microarray analysis, Casati and Walbot (2004) and Ulm et al. (2004) identified more than 100 UV-B responsive genes in maize and Arabidopsis, respectively. Yannarelli et al. (2006b) indicated that the up-regulation of HO-1 mRNA occurs in a manner similar to that found in other genes implicated in the 
UV-B response. These results are the most comprehensive data currently available on the effects of solar UV-B on plant gene expression, and the actual signal transduction pathways activated by UV-B radiation are not yet well defined (Stratmann et al., 2000; Miles et al., 2002).

Earlier research indicated that plant MYB transcription factors regulate plant anthocyanin and phlobaphene biosynthesis (Dooner et al., 1991), trichome differentiation (Oppenheimer et al., 1991), epidermal cell shape determination (Noda et al., 1994), and gibberellin-regulated gene activation (Gubler et al., 1995). Shimizu et al. (2000) isolated and characterized a subfamily of GmMYB29 genes whose expression was found to be significantly upregulated upon UV-B irradiation. GmMZB29 consists of at least four closely related genes, which were classified into two groups based on their sequence similarity; groups A, and B. Expression of the group A members of the GmMYB29 subfamily was found to reach its peak within two hours after the onset of UV-B irradiation when the accumulation of GmCUS mRNA was still increasing. Similar time lag in the induction of an activator and its target genes has been reported in some other cases. For example, the expression of Arabidopsis thatiana Lhcb3 (Light-harvesting chlorophyll $\mathrm{a} / \mathrm{b}$ binding protein) is induced by light irradiation for 1 hour and its mRNA accumulation increased even under continuous light irradiation up to 12 hours, whereas in CC41, which encodes a putative transcription factor of Lhcb3, the peak of mRNA accumulation was reached after irradiation for 1 hour (Wang et al., 1997).

Spraying plants with antioxidants prior to UV-B treatment can block the increase in pathogen-related transcripts and the decrease in photosynthetic transcripts (Surplus et al., 1998; Mackerness et al., 1999). This was an indication that ROS were involved in the pathway leading to changes in the level of these transcripts in response to UV-B radiation. To assess the role of ROS in the induction of HO-1 transcript levels, Yannarelli et al. (2006a) evaluated the action of AsA pre-treatment on the effects of UV-B. Consistent with the involvement of ROS in the regulation of HO-1 gene expression in response to UV-B, the increase in transcripts was blocked by pre-treatment with AsA.

Measuring DNA damage in higher plants is important in assessing the impacts of increased UV, and in testing the relationship of productivity to DNA damage and repair (Bennett et al., 2001). We still do not have a complete understanding of the molecular bases of these responses, but they generally are the result of signal perception by receptor molecules and transduction of a response signal to the cellular machinery, a part of which may regulate gene expression. However, Xu et al. (2008b) did not detect protein effects involved in the signal transduction, because many of the proteins involved in the signal transduction occurred in too low abundance in crude extracts and membrane proteins were usually under-represented on 2-D PAGE gels.

Also research at the mRNA level may not necessarily translate into the quantity and quality of the final gene products, i.e. the proteins. There is a loose correlation between mRNA and protein levels, especially for chloroplast genes, which are usually controlled at the post-transcriptional level (Mackerness et al., 1997). Moreover, many proteins undergo post-translational modifications (PTM) such as removal of signal 
peptides, phosphorylation and glycosylation, which are extremely important for protein activities and subcellular localizations. Therefore, changes at the mRNA level alone may not adequately assess the response to UV-B, and it is necessary to study the effects of UV-B at the protein level. There has been only limited research on the effects of UV-B on proteins, and most of this research focused on a single protein, such as PR-1 (Green and Fluhr, 1995), glutathione reductase, ascorbate peroxidase, superoxide dismutase (Rao et al., 1996) or nitrite reductase (Migge et al., 1998), and heme oxygenase (Yannarelli et al., 2006b).

Suchar and Robberecht (2014) developed a process-based model integrating the effects of UV-B radiation through epidermis, cellular DNA, and its consequences to the leaf expansion. They found that enhanced UV-B radiation induced DNA damage significantly delayed cell division, resulting in significant reductions in leaf growth and development. Leaf expansion was highly dependent on the number of cyclobutane pyrimidine dimers (CPD) present in the DNA, as a result of UV-B radiation dose, quantitative and qualitative absorptive properties of epidermal pigments, and repair mechanisms. Therefore, a thorough understanding the molecular basis of the UV-B response needs in depth research on proteome.

\section{Summary}

Based on available information in regard to the effects of the enhanced UV-B radiation on crops, the general responses of UV-B radiation could be proposed as in Figure 1 to illustrate the complexity of the interactions among factors. The adaptation or acclimation to photooxidative stress is multifactorial and many factors are involved in the overall defense strategy of the plant. A more indepth understanding of the generation and scavenging of AOS is needed before this relationship can be fully understood.

Notwithstanding substantial new knowledge of molecular, cellular and organismal UV-B responses, there remains a clear gap in our understanding of the interactions between these organizational levels, and how they control plant architecture. It remains unproven whether UV-induced morphological changes have a protective function involving shading and decreased leaf penetration of UV-B, counterbalancing trade-offs such as decreased photosynthetic light capture and plant-competitive abilities. Future research will need to disentangle seemingly contradictory interactions occurring at the threshold UV dose where regulation and stress-induced morphogenesis overlap.

Due to our lack in understanding of functional significance of natural variations in phenylpropanoid levels, there is a knowledge gap regarding the photocontrol of phenylpropanoid accumulation under field conditions, and the dynamics of specific compound accumulation, localization patterns and constitutive or background levels of UV-screening compounds warrant further studies. The mechanism of plant hormones including SA- and JA-induced resistance to UV-B radiation is still unclear. A thorough understanding the molecular basis of the UV-B response needs in depth research on proteome. 
Figure 1. Interactions among factors and mechanism involved in preventing $U V-B$ radiation damages

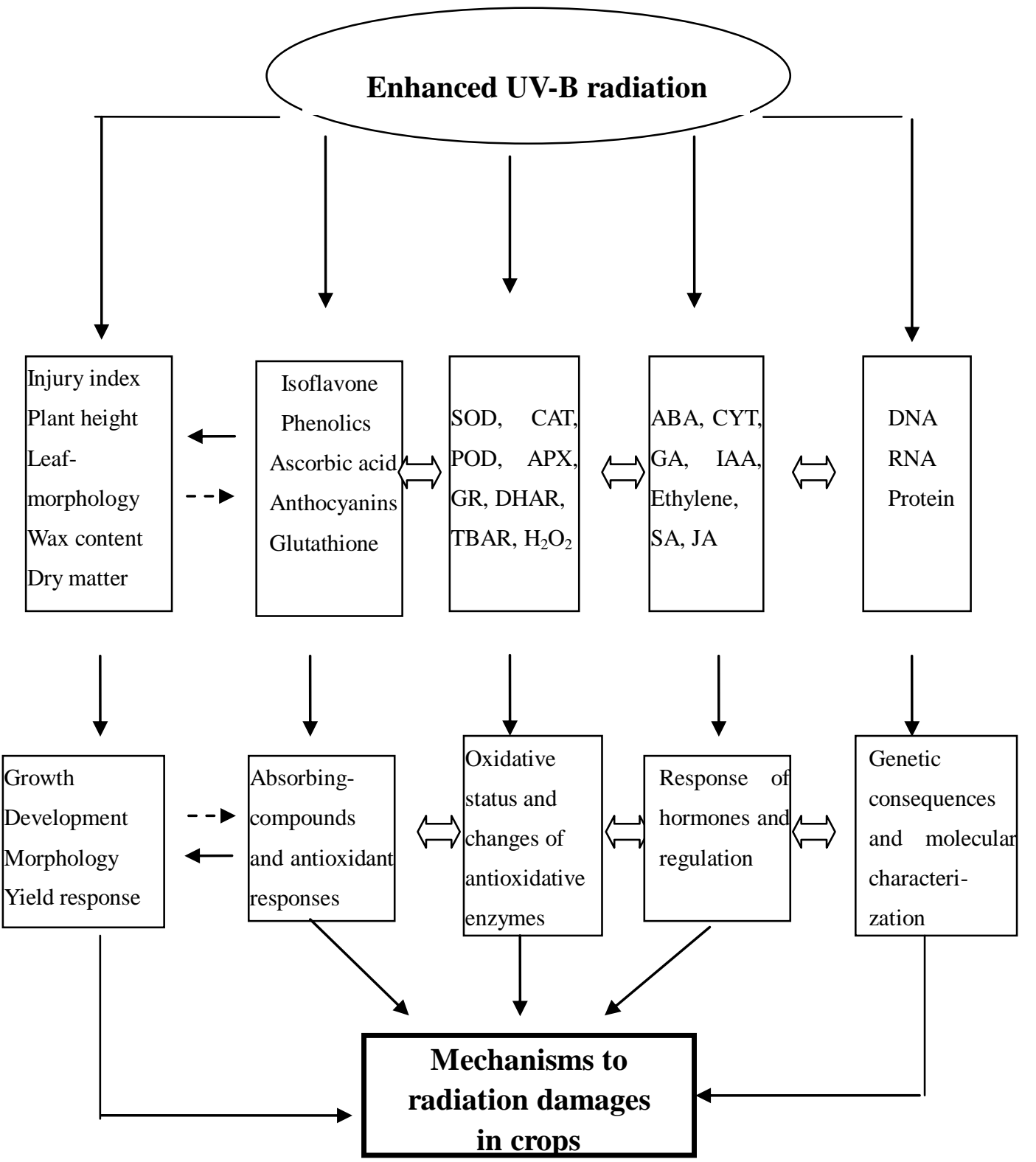

Three specific researches are urgently needed, they are: (1) to differentiate the main UV-absorbing compounds and non-enzymatic antioxidants in contributing to defense system, (2) to investigate the specific role of phytohormones in response to UV-B radiation, and (3) to identify genetic consequences caused by full-season UV-B radiation and fill in the knowledge gap regarding the photocontrol mechanisms of UV-B to crops under field conditions.

Acknowledgments. The work presented in this paper was partially funded by grants from Ministry of Science and Technology of China (2014BAD11B01-A01) and Grand Project of Heilongjiang Provincial Government, China (GA14B101-A01). 


\section{REFERENCES}

[1] Agrawal, S.B., Rathore, D. (2007): Changes in oxidative stress defense system in wheat (Triticum aestivum L.) and mung bean (Vigna radiata L.) cultivars grown with and without mineral nutrients and irradiated by supplemental ultraviolet-B. -Environmental and Experimental Botany 59: 21-33.

[2] Akada, S., Dube, S.K. (1995): Organization of soybean chalcone synthase gene clusters and characterization of a new member of the family. -Plant Molecular Biology 29: 189-199.

[3] Alexieva, V., Sergiev, I., Mapelli, S., Karanov, E. (2001): The effect of drought and ultraviolet radiation on growth and stress markers in pea and wheat. -Plant Cell and Environment 24: 1337-1344.

[4] Allen, D.J., McKee, I.F., Farage, P.K., Baker, N.R. (1997): Analysis of limitations to $\mathrm{CO}_{2}$ assimilation on exposure of leaves of two Brassica napus cultivars to UV-B. -Plant Cell and Environment 20: 633-640.

[5] Alonso, R., Berli, F.J., Bottini, R., Piccoli, P. (2015): Acclimation mechanisms elicited by sprayed abscisic acid, solar UV-B and water deficit in leaf tissues of field-grown grapevines. -Plant Physiology and Biochemistry 91: 56-60.

[6] Ambasht, N.K., Agrawal, M. (1998): Physiological and biochemical responses of Sorghum vulgare plants to supplemental ultraviolet-B radiation. -Canadian Journal of Botany-Revue Canadienne De Botanique 76: 1290-1294.

[7] Anderson, J.W., Foyer, C.H., Walker, D.A. (1983): Light-dependent reduction of dehydroascorbate and uptake of exogenous ascorbate by spinach-chloroplasts. -Planta 158: 442-450.

[8] Arnott, T., Murphy, T.M. (1991): A comparison of the effects of a fungal elicitor and ultraviolet-radiation on ion-transport and hydrogen-peroxide synthesis by rose cells. -Environmental and Experimental Botany 31: 209-216.

[9] Arora, A., Sairam, R.K., Srivastava, G.C. (2002): Oxidative stress and antioxidative system in plants. -Current Science 82: 1227-1238.

[10] Asada, K. (1992): Ascorbate peroxidase - a hydrogen peroxide-scavenging enzyme in plants. -Physiologia Plantarum 85: 235-241.

[11] Babu, T.S., Akhtar, T.A., Lampi, M.A., Tripuranthakam, S., Dixon, D.G., Greenberg, B.M. (2003): Similar stress responses are elicited by copper and ultraviolet radiation in the aquatic plant Lemna gibba: Implication of reactive oxygen species as common signals. -Plant and Cell Physiology 44: 1320-1329.

[12] Baker, N.R., Nogues, S., Allen, D.J. (1997): Photosynthesis and Photo Inhibition. -In: Lumsden, P.J. (ed.) Plants and UV-B: Responses to Environmental Change, Cambridge University Press, Cambridge

[13] Ballare, C.L., Caldwell, M.M., Flint, S.D., Robinson, A., Bornman, J.F. (2011): Effects of solar ultraviolet radiation on terrestrial ecosystems. Patterns, mechanisms, and interactions with climate change. -Photochemical \& Photobiological Sciences 10: 226-241.

[14] Ballare, C.L., Scopel, A.L., Sanchez, R.A., Radosevich, S.R. (1992): Photomorphogenic processes in the agricultural environment. -Photochemistry and Photobiology 56: 777-788.

[15] Bandurska, H., Cieslak, M. (2013): The interactive effect of water deficit and UV-B radiation on salicylic acid accumulation in barley roots and leaves. -Environmental and Experimental Botany 94: 9-18. 
[16] Barnes, P.W., Flint, S.D., Caldwell, M.M. (1990): Morphological responses of crop and weed species of different growth forms to ultraviolet-B radiation. -American Journal of Botany 77: 1354-1360.

[17] Baroniya, S.S., Kataria, S., Pandey, G.P., Guruprasad, K.N. (2013): Intraspecific variations in antioxidant defense responses and sensitivity of soybean varieties to ambient UV radiation. -Acta Physiologiae Plantarum 35: 1521-1530.

[18] Beck, E., Burkert, A., Hofmann, M. (1983): Uptake of ascorbate by intact spinach-chloroplasts. -Plant Physiology 73: 41-45.

[19] Beffa, R., Martin, H.V., Pilet, P.E. (1990): In vitro oxidation of indoleacetic-acid by soluble auxin-oxidases and peroxidases from maize roots. -Plant Physiology 94: 485-491.

[20] Beggs, C.J., Schneider-Zeibert, R., Wellman, E. (1985): UV-B Radiation and Sdaptive Mechanisms in Plants. -In: Worrest, R.C. (ed.) Stratospheric Ozone Reduction, Solar Ultraviolet Radiation and Plant Life, Springer Verlag, Berlin

[21] Beggs, C.J., Wellman, E. (1994): Photocontrol of flavonoid synthesis. -In: Kendrick, R.E., Kronenberg, G.H.M. (ed.) Photomorphogenesis in Plants, Kluwer Academic Publishers, Boston

[22] Beligni, M.V., Lamattina, L. (1999): Nitric oxide protects against cellular damage produced by methylviologen herbicides in potato plants. -Nitric Oxide-Biology and Chemistry 3: 199-208.

[23] Belkhadi, A., Hediji, H., Abbes, Z., Nouairi, I., Barhoumi, Z., Zarrouk, M., Chaibi, W., Djebali, W. (2010): Effects of exogenous salicylic acid pre-treatment on cadmium toxicity and leaf lipid content in Linum usitatissimum L. -Ecotoxicology and Environmental Safety 73: 1004-1011.

[24] Bennett, P.V., Hada, M., Hidema, J., Lepre, A.M., Pope, L.C., Quaite, F.E., Sullivan, J.H., Takayanagi, S., Sutherland, J.C., Sutherland, B.M. (2001): Isolation of high molecular length DNA: Alfalfa, pea, rice, sorghum, soybean, and spinach. -Crop Science 41: 167-172.

[25] Breznik, B., Grem, M., Kreft, I., Gaberscik, A. Crop responses to enhanced UV-B radiation. In: Singh, S. N. (ed.). Climate change and crops (Environmental science and engineering). Berlin: Springer, 2009, 269-281.

[26] Bieza, K., Lois, R. (2001): An Arabidopsis mutant tolerant to lethal ultraviolet-B levels shows constitutively elevated accumulation of flavonoids and other phenolics. -Plant Physiology 126: 1105-1115.

[27] Biggs, R.H., Kossuth, S.V. (1978): Effect of ultraviolet-B radiation enhancement under field conditions on potatoes, tomatoes, corn, rice, southern peas, peanut, squash, mustard and radish. UVB Biological and Climatic Effects Research, Final Report, EPA, Washington, D.C.

[28] Bjorn, L.O. (1996) Effects of ozone depletion and increased UVB on terrestrial ecosystems. -International Journal of Environmental Studies 51: 217-243.

[29] Bornman, J.F. (1999): Localisation and functional significance of flavonoids and related compounds. -Stratospheric Ozone Depletion: The Effects of Enhanced UV-B Radiation on Terrestrial Ecosystems: 59-69.

[30] Bowler, C., Vancamp, W., Vanmontagu, M., Inze, D. (1992): Superoxide dismutase and stress tolerance. Annual Review of Plant Physiology and Plant Molecular Biology 43; 83-116.

[31] Bowler, C., Vancamp, W., Vanmontagu, M., Inze, D. (1994): Superoxide-dismutase in plants. -Critical Reviews in Plant Sciences 13: 199-218. 
[32] Bray, C.M., West, C.E. (2005): DNA repair mechanisms in plants: crucial sensors and effectors for the maintenance of genome integrity. -New Phytologist 168: 511-528.

[33] Britt, A.B. (1996): DNA damage and repair in plants. -Annual Review of Plant Physiology and Plant Molecular Biology 47: 75-100.

[34] Britt, A.B., Chen, J.J., Wykoff, D., Mitchell, D. (1993): A UV-sensitive mutant of arabidopsis defective in the repair of pyrimidine-pyrimidinone(6-4) dimers. -Science 261: 1571-1574.

[35] Britt, A.B., May, G.D. (2003): Re-engineering plant gene targeting. -Trends in Plant Science 8: 90-95.

[36] Burnett, E.C., Desikan, R., Moser, R.C., Neill, S.J. (2000): ABA activation of an MBP kinase in Pisum sativum epidermal peels correlates with stomatal responses to ABA. -Journal of Experimental Botany 51: 197-205.

[37] Caldwell, M., Teramura, A.H., Tevini, M., Bornman, J.F., Bjorn, L.O., Kulandaivelu, G. (1995): Effects of increased solar ultraviolet-radiation on terrestrial plants. -Ambio 24: 166-173.

[38] Caldwell, M.M., Ballare, C.L., Bornman, J.F., Flint, S.D., Bjorn, L.O., Teramura, A.H., Kulandaivelu, G., Tevini, M. (2003): Terrestrial ecosystems increased solar ultraviolet radiation and interactions with other climatic change factors. -Photochemical \& Photobiological Sciences 2: 29-38.

[39] Caldwell, M.M., Flint, S.D., Searles, P.S. (1994): Spectral balance and UV-B sensitivity of soybean - a field experiment. -Plant Cell and Environment 17: 267-276.

[40] Caldwell, M.M., Robberecht, R., Flint, S.D. (1983): Internal filters-prospects for UV-acclimation in higher-plants. -Physiologia Plantarum 58: 445-450.

[41] Carletti, P., Masi, A., Wonisch, A., Grill, D., Tausz, M., Ferretti, M. (2003): Changes in antioxidant and pigment pool dimensions in UV-B irradiated maize seedlings. -Environmental and Experimental Botany 50: 149-157.

[42] Cartwright, H.N., Baucom, C., Singh, P., Smith, K.L., Stapleton, A.E. (2001): Intraspecific comparisons reveal differences in the pattern of ultraviolet radiation responses in four maize (Zea mays L.) varieties. -Journal of Photochemistry and Photobiology B-Biology 62: 88-96.

[43] Casati, P., Walbot, V. (2003): Gene expression profiling in response to ultraviolet radiation in maize genotypes with varying flavonoid content. -Plant Physiology 132: 1739-1754.

[44] Casati, P., Walbot, V. (2004): Rapid transcriptome responses of maize (Zea mays) to UV-B in irradiated and shielded tissues. -Genome Biology 5.

[45] Chappell, J., Hahlbrock, K. (1984): Transcription of plant defense genes in response to UV-light or fungal elicitor. -Nature 311: 76-78.

[46] Chen, K., Feng, H., Zhang, M., Wang, X. (2003): Nitric oxide alleviates oxidative damage in the green alga Chlorella pyrenoidosa caused by UV-B radiation. -Folia Microbiologica 48: 389-393.

[47] Chen, M., Chory, J., Fankhauser, C. (2004): Light signal transduction in higher plants. -Annual Review of Genetics 38: 87-117.

[48] Choudhury, S., Panda, S.K. (2004) Role of salicylic acid in regulating cadmium induced oxidative stress in Oryza sativa L. roots. -Bulgarian Journal of Plant Physiology 30: 95-110.

[49] Corpas, F.J., Palma, J.M., Sandalio, L.M., Lopez-Huertas, E., Romero-Puertas, M.C., Barroso, J.B., Del Rio, L.A. (1999): Purification of catalase from pea leaf peroxisomes: 
Identification of five different isoforms. -Free Radical Research 31: S235-S241.

[50] Correia, C.M., Areal, E.L.V., Torres-Pereira, M.S., Torres-Pereira, J.M.G. (1999): Intraspecific variation in sensitivity to ultraviolet-B radiation in maize grown under field conditions - II. Physiological and biochemical aspects. -Field Crops Research 62: 97-105.

[51] Costa, H., Gallego, S.M., Tomaro, M.L. (2002): Effect of UV-B radiation on antioxidant defense system in sunflower cotyledons. -Plant Science 162: 939-945.

[52] Dai, Q.J., Peng, S.B., Chavez, A.Q., Vergara, B.S. (1994): Intraspecific responses of 188 rice cultivars to enhanced UVB radiation. -Environmental and Experimental Botany 34: 433-442.

[53] Dai, Q.J., Yan, B., Huang, S.B., Liu, X.Z., Peng, S.B., Miranda, M.L.L., Chavez, A.Q., Vergara, B.S., Olszyk, D.M. (1997): Response of oxidative stress defense systems in rice (Oryza sativa) leaves with supplemental UV-B radiation. -Physiologia Plantarum 101: 301-308.

[54] Davies, K.J. (1986): Intracellular proteolytic systems may function as secondary antioxidant defenses: an hypothesis. -Journal of Free Radicals in Biology \& Medicine 2: 155-173.

[55] Day, T.A. (1993): Relating UV-B radiation screening effectiveness of foliage to absorbing-compound concentration and anatomical characteristics in a diverse group of plants. -Oecologia 95: 542-550.

[56] Day, T.A., Vogelmann, T.C., Delucia, E.H. (1992): Are some plant life forms more effective than others in screening out ultraviolet-B radiation. -Oecologia 92: 513-519.

[57] Dayan, J., Voronin, N., Gong, F., Sun, T.-p., Hedden, P., Fromm, H., Aloni, A. (2012): Leaf-Induced Gibberellin Signaling Is Essential for Internode Elongation, Cambial Activity, and Fiber Differentiation in Tobacco Stems. -Plant Cell 24: 66-79.

[58] Dooner, H.K., Robbins, T.P., Jorgensen, R.A. (1991): Genetic and developmental control of anthocyanin biosynthesis. -Annual Review of Genetics 25: 173-199.

[59] Doughty, C.J., Hope, A.B. (1973): Effects of ultraviolet radiation on the membranes of Chara corallina. -The Journal of Membrane Biology 13: 185-198.

[60] Dsurney, S.J., Tschaplinski, T.J., Edwards, N.T., Shugart, L.R. (1993): Biological responses of 2 soybean cultivars exposed to enhanced UVB radiation. -Environmental and Experimental Botany 33: 347-356.

[61] Ervin, E.H., Zhang, X.Z., Fike, J.H. (2004): Ultraviolet-B radiation damage on Kentucky Bluegrass II: Hormone supplement effects. -Hortscience 39: 1471-1474.

[62] Feng, H.Y., An, L.Z., Chen, T., Qiang, W.Y., Xu, S.J., Zhang, M.X., Wang, X.L., Cheng, G.D. (2003): The effect of enhanced ultraviolet-B radiation on growth, photosynthesis and stable carbon isotope composition $(\delta \mathrm{C}-13)$ of two soybean cultivars (Glycine max) under field conditions. -Environmental and Experimental Botany 49: 1-8.

[63] Feng, H.Y., Chen, T., Xu, S.J., An, L.Z., Qiang, W.Y., Zhang, M.X., Wang, X.L. (2001): Effect of enhanced UV-B radiation on growth, yield and stable carbon isotope composition in Glycine max cultivars. -Acta Botanica Sinica 43: 709-713.

[64] Flint, S.D., Searles, P.S., Caldwell, M.M. (2004): Field testing of biological spectral weighting functions for induction of UV-absorbing compounds in higher plants. -Photochemistry and Photobiology 79: 399-403.

[65] Foyer, C.H., Lelandais, M., Kunert, K.J. (1994): Photooxidative stress in plants. -Physiologia Plantarum 92: 696-717.

[66] Galatro, A., Simontacchi, M., Puntarulo, S. (2001): Free radical generation and antioxidant content in chloroplasts from soybean leaves exposed to ultraviolet-B. 
-Physiologia Plantarum 113: 564-570.

[67] Gerhardt, K.E., Wilson, M.I., Greenberg, B.M. (1999): Tryptophan photolysis leads to a UVB-induced $66 \mathrm{kDa}$ photoproduct of ribulose-1, 5-bisphosphate carboxylase/oxygenase (Rubisco) in vitro and in vivo. -Photochemistry and Photobiology 70: 49-56.

[68] Germ, M., Mazej, Z., Gaberšcik, A., Trošt Sedej, T. (2006): The response of Ceratophyllum demersum $\mathrm{L}$. and

Myriophyllum spicatum L. to reduced, ambient, and enhanced ultraviolet-B radiation.

-Hydrobiologia (Den Haag) 570: 47-51.

[69] Germ, M., Stibilj, V., Kreft, S., Gaberšcik, A., Pajk, F., Kreft, I. (2009): Selenium concentration in St. John's wort (Hypericum perforatum L.) herb after foliar spraying of young plants under different UV-B radiation levels. -Food Chemistry 117: 204-206.

[70] Germ, M., Spahic, I., Gaberšcik, A. (2015): Morphological, biochemical and physiological responses of Indian cress (Tropaeolum majus) to elevated UV-B radiation. -Periodicum Biologorum 117 (3): 357-364.

[71] Giordano, C.V., Galatro, A., Puntarulo, S., Ballare, C.L. (2004): The inhibitory effects of UV-B radiation (280-315 $\mathrm{nm}$ ) on Gunnera magellanica growth correlate with increased DNA damage but not with oxidative damage to lipids. -Plant Cell and Environment 27: 1415-1423.

[72] Gould, K.S., McKelvie, J., Markham, K.R. (2002): Do anthocyanins function as antioxidants in leaves? Imaging of $\mathrm{H}_{2} \mathrm{O}_{2}$ in red and green leaves after mechanical injury. -Plant Cell and Environment 25: 1261-1269.

[73] Green, R., Fluhr, R. (1995): UV-B-induced PR-1 accumulation is mediated by active oxygen species. -Plant Cell 7: 203-212.

[74] Grill, E., Winnacker, E.L., Zenk, M.H. (1985): Phytochelatins - the principal heavy-metal complexing peptides of higher-plants. -Science 230: 674-676.

[75] Gubler, F., Kalla, R., Roberts, J.K., Jacobsen, J.V. (1995): Gibberellin-regulated expression of a myb gene in barley aleurone cells - evidence for myb transactivation of a high-pl alpha-amylase gene promoter. -Plant Cell 7: 1879-1891.

[76] Häder, D.P., Helbling, E.W., Williamson, C.E., Worrest, R.C. (2011): Effects of UV radiation on aquatic ecosystems and interactions with climate change. -Photochemical \& Photobiological Sciences 10: 242-260.

[77] Harborne, J.B., Williams, C.A. (2000): Advances in flavonoid research since 1992. -Phytochemistry 55: 481-504.

[78] Hargreaves, A., Taiwo, F.A., Duggan, O., Kirk, S.H., Ahmad, S.I. (2007): Near-ultraviolet photolysis of beta-phenylpyruvic acid generates free radicals and results in DNA damage. -Journal of Photochemistry and Photobiology B-Biology 89: 110-116.

[79] Hayat, S., Maheshwari, P., Wani, A.S., Irfan, M., Alyemeni, M.N., Ahmad, A. (2012): Comparative effect of 28 homobrassinolide and salicylic of $\mathrm{NaCl}$ stress in Brassica juncea L. -Plant Physiology and Biochemistry 53: 61-68.

[80] Hideg, E., Nagy, T., Oberschall, A., Dudits, D., Vass, I. (2003): Detoxification function of aldose/aldehyde reductase during drought and ultraviolet-B $(280-320 \mathrm{~nm})$ stresses. -Plant Cell and Environment 26: 513-522.

[81] Hidema, J., Kumagai, T. (2006): Sensitivity of rice to ultraviolet-B radiation. -Annals of Botany 97: 933-942.

[82] Hofmann, R.W., Swinny, E.E., Bloor, S.J., Markham, K.R., Ryan, K.G., Campbell, B.D., Jordan, B.R., Fountain, D.W. (2000): Responses of nine Trifolium repens L. populations to ultraviolet-B radiation: Differential flavonol glycoside accumulation and biomass 
production. -Annals of Botany 86: 527-537.

[83] Huang, S.B., Dai, Q.J., Peng, S.B., Chavez, A.Q., Miranda, L.L., Visperas, R.M., Vergara, B.S. (1997): Influence of supplemental ultraviolet-B on indoleacetic acid and calmodulin in the leaves of rice (Oryza sativa L). -Plant Growth Regulation 21: 59-64.

[84] Huang, X.H., Zhou, Q., Zhang, G.S. (2005): Advances on rare earth application in pollution ecology. -Journal of Rare Earths 23: 5-11.

[85] Hutzler, P., Fischbach, R., Heller, W., Jungblut, T.P., Reuber, S., Schmitz, R., Veit, M., Weissenbock, G., Schnitzler, J.P. (1998): Tissue localization of phenolic compounds in plants by confocal laser scanning microscopy. -Journal of Experimental Botany 49: 953-965.

[86] Izaguirre, M.M., Mazza, C.A., Svatos, A., Baldwin, I.T., Ballare, C.L. (2007): Solar ultraviolet-B radiation and insect herbivory trigger partially overlapping phenolic responses in Nicotiana attenuata and Nicotiana longiflora. -Annals of Botany 99: 103-109.

[87] Izaguirre, M.M., Scopel, A.L., Baldwin, I.T., Ballare, C.L. (2003): Convergent responses to stress. Solar ultraviolet-B radiation and Manduca sexta herbivory elicit overlapping transcriptional responses in field-grown plants of Nicotiana longiflora. -Plant Physiology 132: $1755-1767$.

[88] Jain, K., Kataria, S., Guruprasad, K.N. (2004): Effect of UV-B radiation on antioxidant enzymes and its modulation by benzoquinone and alpha-tocopherol in cucumber cotyledons. -Current Science 87: 87-90.

[89] Jansen, M.A.K., Gaba, V., Greenberg, B.M. (1998): Higher plants and UV-B radiation: Balancing damage, repair and acclimation. -Trends in Plant Science 3: 131-135.

[90] Jimenez, A., Hernandez, J.A., delRio, L.A., Sevilla, F. (1997): Evidence for the presence of the ascorbate-glutathione cycle in mitochondria and peroxisomes of pea leaves. -Plant Physiology 114: 275-284.

[91] Jordan, B.R. (2002): Molecular response of plant cells to UV-B stress. -Functional Plant Biology 29: 909-916.

[92] Jordan, B.R., James, P.E., Mackerness, S.A.H. (1998): Factors affecting UV-B-induced changes in Arabidopsis thaliana L. gene expression: the role of development, protective pigments and the chloroplast signal. -Plant and Cell Physiology 39: 769-778.

[93] Kakani, V.G., Reddy, K.R., Zhao, D., Gao, W. (2004): Senescence and hyperspectral reflectance of cotton leaves exposed to ultraviolet-B radiation and carbon dioxide. -Physiologia Plantarum 121: 250-257.

[94] Kalbina, I., Strid, A. (2006): Supplementary ultraviolet-B irradiation reveals differences in stress responses between Arabidopsis thaliana ecotypes. -Plant Cell and Environment 29: 754-763.

[95] Karioti, A., Kitsaki, C.K., Zygouraki, S., Ziobora, M., Djeddi, S., Skaltsa, H., Liakopoulos, G. (2008): Occurrence of flavonoids in Ophrys (Orchidaceae) flower parts. -Flora 203: 602-609.

[96] Kakani, V.G., Reddy, K.R., Zhao, D., Sailaja, K. (2003): Field crop responses to ultraviolet-B radiation: a review. Agricultural and Forest Meteorology 120: 191-218.

[97] Kataria, S., Guruprasad, K.N. (2012a): Intraspecific variations in growth, yield and photosynthesis of sorghum varieties to ambient UV (280-400 nm) radiation. -Plant Science 196: 85-92.

[98] Kataria, S., Guruprasad, K.N. (2012b): Solar UV-B and UV-A/B exclusion effects on intraspecific variations in crop growth and yield of wheat varieties. -Field Crops Research 
125: 8-13.

[99] Keiller, D.R., Holmes, M.G. (2001): Effects of long-term exposure to elevated UV-B radiation on the photosynthetic performance of five broad-leaved tree species. -Photosynthesis Research 67: 229-240.

[100] Kochevar, I.E. (1990): UV-induced protein alterations and lipid oxidation in erythrocyte-membranes. -Photochemistry and Photobiology 52: 795-800.

[101] Kondo, N., Kawashima, M. (2000): Enhancement of the tolerance to oxidative stress in cucumber (Cucumis sativus L.) seedlings by UV-B irradiation: Possible involvement of phenolic compounds and antioxidative enzymes. -Journal of Plant Research 113: 311-317.

[102] Koti, S., Reddy, K.R., Kakani, V.G., Zhao, D., Gao, W. (2007): Effects of carbon dioxide, temperature and ultraviolet-B radiation and their interactions on soybean (Glycine max L.) growth and development. -Environmental and Experimental Botany 60: 1-10.

[103] Kreft, S., Strukelj, B., Gaberscik, A., Kreft, I. (2002): Rutin in buckwheat herbs grown at different UV-B radiation levels: comparison of two UV spectrophotometric and an HPLC method. -Journal of Experimental Botany 53: 1801-1804.

[104] Kumagai, T., Hidema, J., Kang, H.S., Sato, T. (2001): Effects of supplemental UV-B radiation on the growth and yield of two cultivars of Japanese lowland rice (Oryza saliva L.) under the field in a cool rice-growing region of Japan. -Agriculture Ecosystems \& Environment 83: 201-208.

[105] Laakso, K., Sullivan, J.H., Huttunen, S. (2000): The effects of UV-B radiation on epidermal anatomy in loblolly pine (Pinus taeda L.) and Scots pine (Pinus sylvestris L.). -Plant Cell and Environment 23: 461-472.

[106] Lachno, D.R., Baker, D.A. (1986): Stress induction of abscisic-acid in maize roots. -Physiologia Plantarum 68: 215-221.

[107] Lagarias, J.C., Kelly, J.M., Cyr, K.L., Smith, W.O. (1987): Comparative photochemical analysis of highly purified 124 kilodalton oat and rye phytochromes in vivo. Photochemistry and Photobiology 46: 5-13.

[108] Landry, L.G., Chapple, C.C.S., Last, R.L. (1995): Arabidopsis mutants lacking phenolic sunscreens exhibit enhanced ultraviolet-b injury and oxidative damage. -Plant Physiology 109: 1159-1166.

[109] Landry, L.G., Stapleton, A.E., Lim, J., Hoffman, P., Hays, J.B., Walbot, V., Last, R.L. (1997): An Arabidopsis photolyase mutant is hypersensitive to ultraviolet-B radiation. -Proceedings of the National Academy of Sciences of the United States of America 94: 328-332.

[110] Larkindale, J., Knight, M.R. (2002): Protection against heat stress-induced oxidative damage in arabidopsis involves calcium, abscisic acid, ethylene, and salicylic acid. -Plant Physiology 128: 682-695.

[111] Larson, R.A. (1988): The antioxidants of higher-plants. -Phytochemistry 27: 969-978.

[112] Latifi, A., Ruiz, M., Zhang, C.-C. (2009): Oxidative stress in cyanobacteria. -FEMS Microbiology Reviews 33: 258-278.

[113] Levizou, E., Manetas, Y. (2002): Spectrophotometric assessment of leaf UV-B absorbing compounds and chemically determined total phenolic levels are strongly correlated. -Canadian Journal of Botany-Revue Canadienne De Botanique 80: 690-694.

[114] Li, J.Y., Oulee, T.M., Raba, R., Amundson, R.G., Last, R.L. (1993): Arabidopsis flavonoid mutants are hypersensitive to UV-B irradiation. -Plant Cell 5: 171-179.

[115] Li, X.M., Ma, L.J., Bu, N., Li, Y.Y., Zhang, L.H. (2014): Effects of salicylic acid 
pre-treatment on cadmium and/or UV-B stress in soybean seedlings. -Biologia Plantarum 58: 195-199.

[116] Li, X.M., Zhang, L.H., Li, Y.Y., Ma, L.J., Bu, N., Ma, C.Y. (2012): Changes in photosynthesis, antioxidant enzymes and lipid peroxidation in soybean seedlings exposed to UV-B radiation and/or Cd. -Plant and Soil 352: 377-387.

[117] Li, Y., He, L.L., Zu, Y.Q. (2010): Intraspecific variation in sensitivity to ultraviolet-B radiation in endogenous hormones and photosynthetic characteristics of 10 wheat cultivars grown under field conditions. -South African Journal of Botany 76: 493-498.

[118] Li, Y., Zu, Y.Q., Chen, J.J., Chen, H.Y. (2002): Intraspecific responses in crop growth and yield of 20 soybean cultivars to enhanced ultraviolet-B radiation under field conditions. -Field Crops Research 78: 1-8.

[119] Li, Y., Zu, Y.Q., Chen, J.J., Chen, H.Y., Yang, J.L., Hu, Z.D. (2000): Intraspecific differences in physiological response of 20 wheat cultivars to enhanced ultraviolet-B radiation under field conditions. Environmental and Experimental Botany 44: 95-103.

[120] Liu, B., Liu, X.B., Li, Y.S., Herbert, S.J. (2013): Effects of enhanced UV-B radiation on seed growth characteristics and yield components in soybean. -Field Crops Research 154: 158-163.

[121] Liu, B., Liu, X.B., Wang, C., Jin, J., Herbert, S.J. (2010): Endogenous hormones in seed, leaf, and pod wall and their relationship to seed filling in soybeans. -Crop \& Pasture Science 61: 103-110.

[122] Liu, L., McClure, J.W. (1995): Effects of UV-B on activities of enzymes of secondary phenolic metabolism in barley primary leaves. -Physiologia Plantarum 93: 734-739.

[123] Logemann, E., Wu, S.C., Schroder, J., Schmelzer, E., Somssich, I.E., Hahlbrock, K. (1995): Gene activation by UV light, fungal elicitor or fungal infection in Petroselinum crispum is correlated with repression of cell cycle-related genes. -Plant Journal 8: 865-876.

[124] Lois, R., Buchanan, B.B. (1994): Severe sensitivity to ultraviolet-radiation in an arabidopsis mutant deficient in flavonoid accumulation .2. mechanisms of uv-resistance in Arabidopsis. -Planta 194: 504-509.

[125] Luo, A.D., Qian, Q., Yin, H.F., Liu, X.Q., Yin, C.X., Lan, Y., Tang, J.Y., Tang, Z.S., Cao, S.Y., Wang, X.J., Xia, K., Fu, X.D., Luo, D., Chu, C.C. (2006): EUI1, encoding a putative cytochrome P450 monooxygenase, regulates internode elongation by modulating gibberellin responses in rice. -Plant and Cell Physiology 47: 181-191.

[126] Mackerness, S.A.H., John, C.F., Jordan, B., Thomas, B. (2001): Early signaling components in ultraviolet-B responses: distinct roles for different reactive oxygen species and nitric oxide. -FEBS Letters 489: 237-242.

[127] Mackerness, S.A.H., Surplus, S.L., Blake, P., John, C.F., Buchanan-Wollaston, V., Jordan, B.R., Thomas, B. (1999): Ultraviolet-B-induced stress and changes in gene expression in Arabidopsis thaliana: role of signalling pathways controlled by jasmonic acid, ethylene and reactive oxygen species. -Plant Cell and Environment 22: 1413-1423.

[128] Mackerness, S.A.H., Thomas, B., Jordan, B.R. (1997): The effect of supplementary ultraviolet-B radiation on mRNA transcripts, translation and stability of chloroplast proteins and pigment formation in Pisum sativum L. -Journal of Experimental Botany 48: 729-738.

[129] Mahdavian, K., Kalantari, K.M., Ghorbanli, M., Torkzade, M. (2008): The effects of salicylic acid on pigment contents in ultraviolet radiation stressed pepper plants. -Biologia Plantarum 52: 170-172. 
[130] Malanga, G., Kozak, R.G., Puntarulo, S. (1999): N-acetylcysteine-dependent protection against UV-B damage in two photosynthetic organisms. -Plant Science 141: 129-137.

[131] Markham, K.R., Ryan, K.G., Bloor, S.J., Mitchell, K.A. (1998): An increase in the luteolin : apigenin ratio in Marchantia polymorpha on UV-B enhancement. -Phytochemistry 48: 791-794.

[132] Matysik, J., Alia, Bhalu, B., Mohanty, P. (2002): Molecular mechanisms of quenching of reactive oxygen species by proline under stress in plants. -Current Science 82: 525-532.

[133] Mazza, C.A., Battista, D., Zima, A.M., Szwarcberg-Bracchitta, M., Giordano, C.V., Acevedo, A., Scopel, A.L., Ballare, C.L. (1999): The effects of solar ultraviolet-B radiation on the growth and yield of barley are accompanied by increased DNA damage and antioxidant responses. -Plant Cell and Environment 22: 61-70.

[134] Mazza, C.A., Boccalandro, H.E., Giordano, C.V., Battista, D., Scopel, A.L., Ballare, C.L. (2000): Functional significance and induction by solar radiation of ultraviolet-absorbing sunscreens in field-grown soybean crops. -Plant Physiology 122: 117-125.

[135] McNamara, A.E., Hill, W.R. (2000): UV-B irradiance gradient affects photosynthesis and pigments but not food quality of periphyton. -Freshwater Biology 43: 649-662.

[136] Miles, G.P., Samuel, M.A., Ellis, B.E. (2002): Suramin inhibits oxidant signalling in tobacco suspension-cultured cells. -Plant Cell and Environment 25: 521-527.

[137] Mishra, V., Mishra, P., Srivastava, G., Prasad, S.M. (2011): Effect of dimethoate and UV-B irradiation on the response of antioxidant defense systems in cowpea (Vigna unguiculata L.) seedlings. -Pesticide Biochemistry and Physiology 100: 118-123.

[138] Mislevy, P., Boote, K.J., Martin, F.G. (1988): Soybean response to gibberellic-acid .1. time of application relative to emergence. -Field Crops Research 19: 113-121.

[139] Murali, N.S., Teramura, A.H. (1986): Effects of supplemental ultraviolet-B radiation on the growth and physiology of field-grown soybean. -Environmental and Experimental Botany 26: 233-242.

[140] Murali, N.S., Teramura, A.H., Randall, S.K. (1988): Response differences between 2 soybean cultivars with contrasting UV-B radiation sensitivities. -Photochemistry and Photobiology 48: 653-657.

[141] Murphy, T.M. (1983): Membranes as targets of ultraviolet-radiation. -Physiologia Plantarum 58: 381-388.

[142] Mutlu, S., Atici, O., Nalbantoglu, B. (2009): Effects of salicylic acid and salinity on apoplastic antioxidant enzymes in two wheat cultivars differing in salt tolerance. -Biologia Plantarum 53: 334-338.

[143] Nazar, R., Iqbal, N., Syeed, S., Khan, N.A. (2011): Salicylic acid alleviates decreases in photosynthesis under salt stress by enhancing nitrogen and sulfur assimilation and antioxidant metabolism differentially in two mungbean cultivars. -Journal of Plant Physiology 168: 807-815.

[144] Newsham, K.K., Robinson, S.A. (2009): Responses of plants in polar regions to UVB exposure: a meta-analysis. -Global Change Biology 15: 2574-2589.

[145] Noctor, G., Foyer, C.H. (1998): Ascorbate and glutathione: Keeping active oxygen under control. -Annual Review of Plant Physiology and Plant Molecular Biology 49: 249-279.

[146] Noda, K., Glover, B.J., Linstead, P., Martin, C. (1994): Flower color intensity depends on specialized cell-shape controlled by a MYB-related transcription factor. -Nature 369: 661-664.

[147] Oppenheimer, D.G., Herman, P.L., Sivakumaran, S., Esch, J., Marks, M.D. (1991): A MYB gene required for leaf trichome differentiation in arabidopsis is expressed in 
stipules. -Cell 67: 483-493.

[148] Pelle, E., Maes, D., Padulo, G.A., Kim, E.K., Smith, W.P. (1990): An invitro model to test relative antioxidant potential - ultraviolet-induced lipid-peroxidation in liposomes. -Archives of Biochemistry and Biophysics 283: 234-240.

[149] Peng, Q., Zhou, Q. (2009): The endogenous hormones in soybean seedlings under the joint actions of rare earth element $\mathrm{La}(\mathrm{III})$ and ultraviolet-B stress. -Biological Trace Element Research 132: 270-277.

[150] Peng, Z.F., Strack, D., Baumert, A., Subramaniam, R., Goh, N.K., Chia, T.F., Tan, S.N., Chia, L.S. (2003): Antioxidant flavonoids from leaves of Polygonum hydropiper L. -Phytochemistry 62: 219-228.

[151] Pignocchi, C., Foyer, C.H. (2003): Apoplastic ascorbate metabolism and its role in the regulation of cell signalling. -Current Opinion in Plant Biology 6: 379-389.

[152] Pinto, M.E., Edwards, G.E., Riquelme, A.A., Ku, M.S.B. (2002): Enhancement of nodulation in bean (Phaseolus vulgaris) by UV-B irradiation. -Functional Plant Biology 29: 1189-1196.

[153] Prasad, S.M., Dwivedi, R., Zeeshan, M. (2005): Growth, photosynthetic electron transport, and antioxidant responses of young soybean seedlings to simultaneous exposure of nickel and UV-B stress. -Photosynthetica 43: 177-185.

[154] Qi, Y.D., Bai, S.J., Heisler, G.M. (2003): Changes in ultraviolet-B and visible optical properties and absorbing pigment concentrations in pecan leaves during a growing season. -Agricultural and Forest Meteorology 120: 229-240.

[155] Rao, M.V., Ormrod, D.P. (1995): Impact of uvb and $\mathrm{O}_{3}$ on the oxygen-free radical scavenging system in Arabidopsis-thaliana genotypes differing in flavonoid biosynthesis. -Photochemistry and Photobiology 62: 719-726.

[156] Rao, M.V., Paliyath, C., Ormrod, D.P. (1996): Ultraviolet-B- and ozone-induced biochemical changes in antioxidant enzymes of Arabidopsis thaliana. -Plant Physiology 110: 125-136.

[157] Reuber, S., Bornman, J.F., Weissenbock, G. (1996): A flavonoid mutant of barley (Hordeum vulgare L.) exhibits increased sensitivity to UV-B radiation in the primary leaf. -Plant Cell and Environment 19: 593-601.

[158] Robberecht, R., Caldwell, M.M. (1978): Leaf epidermal transmittance of ultraviolet-radiation and its implications for plant sensitivity to ultraviolet-radiation induced injury. -Oecologia 32: 277-287.

[159] Robson, T.M., Klem, K., Urban, O., Jansen, M.A.K. (2015): Re-interpreting plant morphological responses to UV-B radiation. -Plant Cell and Environment 38: 856-866.

[160] Ros, J., Tevini, M. (1995): Interaction of UV-radiation and IAA during growth of seedlings and hypocotyl segments of sunflower. -Journal of Plant Physiology 146: 295-302.

[161] Rozema, J., vandeStaaij, J., Bjorn, L.O., Caldwell, M. (1997): UV-B as an environmental factor in plant life: Stress and regulation. -Trends in Ecology \& Evolution 12: 22-28.

[162] Ryan, K.G., Swinny, E.E., Markham, K.R., Winefield, C. (2002): Flavonoid gene expression and UV photoprotection in transgenic and mutant Petunia leaves. -Phytochemistry 59: 23-32.

[163] Salmon, S., Maziere, J.C., Santus, R., Morliere, P., Bouchemal, N. (1990): UVB-induced photoperoxidation of lipids of human low and high-density lipoproteins - a possible role of tryptophan residues. -Photochemistry and Photobiology 52: 541-545.

[164] Saradhi, P.P., Alia, Arora, S., Prasad, K. (1995): Proline accumulates in plants exposed to 
UV-radiation and protects them against UV induced peroxidation. -Biochemical and Biophysical Research Communications 209: 1-5.

[165] Saruhan, N., Saglam, A., Kadioglu, A. (2012): Salicylic acid pretreatment induces drought tolerance and delays leaf rolling by inducing antioxidant systems in maize genotypes. -Acta Physiologiae Plantarum 34: 97-106.

[166] Schmelzer, E., Jahnen, W., Hahlbrock, K. (1988): Insitu localization of light-induced chalcone synthase messenger-RNA, chalcone synthase, and flavonoid end products in epidermal-cells of parsley leaves. -Proceedings of the National Academy of Sciences of the United States of America 85: 2989-2993.

[167] Searles, P.S., Flint, S.D., Caldwell, M.M. (2001): A meta analysis of plant field studies simulating stratospheric ozone depletion. -Oecologia 127: 1-10.

[168] Sharma, A., Guruprasad, K.N. (2009): Similarities in the biochemical changes between solar UV exclusion and GA application in Amaranthus caudatus. -Physiology and Molecular Biology of Plants 15: 367-370.

[169] Sheahan, J.J. (1996): Sinapate esters provide greater UV-B attenuation than flavonoids in Arabidopsis thaliana (Brassicaceae). -American Journal of Botany 83: 679-686.

[170] Shimizu, T., Fujibe, R., Senda, M., Ishikawa, R., Harada, T., Niizeki, M., Akada, S. (2000): Molecular cloning and characterization of a subfamily of UV-B responsive MYB genes from soybean. -Breeding Science 50: 81-90.

[171] Shiu, C.T., Lee, T.M. (2005): Ultraviolet-B-induced oxidative stress and responses of the ascorbate-glutathione cycle in a marine macroalga Ulva fasciata. -Journal of Experimental Botany 56: 2851-2865.

[172] Shweta, M., Agrawal, S.B. (2006): Interactive effects between supplemental ultraviolet-B radiation and heavy metals on the growth and biochemical characteristics of Spinacia oleracea L. -Brazilian Journal of Plant Physiology 18: 307-314.

[173] Singh, M., Singh, S., Agrawal, S.B. (2012): Intraspecific responses of six cultivars of wheat (Triticum aestivum L.) to supplemental ultraviolet-B radiation under field conditions. -Acta Physiologiae Plantarum 34: 65-74.

[174] Skokut, T.A., Wu, J.H., Daniel, R.S. (1977): Retardation of ultraviolet-light accelerated chlorosis by visible-light or by benzyladenine in Nicotiana glutinosa leaves - changes in amino-acid content and chloroplast ultrastructure. -Photochemistry and Photobiology 25: 109-118.

[175] Smith, G.J., Markham, K.R. (1998): Tautomerism of flavonol glucosides: relevance to plant UV protection and flower colour. -Journal of Photochemistry and Photobiology a-Chemistry 118: 99-105.

[176] Smrkolj, P., Stibilj, V., Kreft, I., Germ, M. (2006): Selenium species in buckwheat cultivated with foliar addition of $\mathrm{Se}(\mathrm{VI})$ and various levels of UV-B radiation, Food Chemistry 96: 675-681.

[177] Stapleton, A.E., Walbot, V. (1994): Flavonoids can protect maize DNA from the induction of ultraviolet-radiation damage. -Plant Physiology 105: 881-889.

[178] Stratmann, J. (2003): Ultraviolet-B radiation co-opts defense signaling pathways. -Trends in Plant Science 8: 526-533.

[179] Strid, A., Chow, W.S., Anderson, J.M. (1994): UV-B damage and protection at the molecular-level in plants. -Photosynthesis Research 39: 475-489.

[180] Suchar, V.A., Robberecht, R. (2015): Integration and scaling of UV-B radiation effects on plants: from DNA to leaf. -Ecology and Evolution 5: 2544-2555.

[181] Sullivan, J.H., Gitz, D.C., III, Liu-Gitz, L., Xu, C., Gao, W., Slusser, J. (2007): Coupling 
short-term changes in ambient UV-B levels with induction of UV-screening compounds. -Photochemistry and Photobiology 83: 863-870.

[182] Sullivan, J.H., Teramura, A.H. (1990): Field-study of the interaction between solar ultraviolet-b radiation and drought on photosynthesis and growth in soybean. -Plant Physiology 92: 141-146.

[183] Surplus, S.L., Jordan, B.R., Murphy, A.M., Carr, J.P., Thomas, B., Mackerness, S.A.H. (1998): Ultraviolet-B-induced responses in Arabidopsis thaliana: role of salicylic acid and reactive oxygen species in the regulation of transcripts encoding photosynthetic and acidic pathogenesis-related proteins. -Plant Cell and Environment 21: 685-694.

[184] Taalas, P., Kaurola, J., Kylling, A., Shindell, D., Sausen, R., Dameris, M., Grewe, V., Herman, J. (2000): The impact of greenhouse gases and halogenated species on future solar UV radiation doses. -Geophysical Research Letters 27: 1127-1130.

[185] Takahama, U., Oniki, T. (2000): Flavonoids and some other phenolics as substrates of peroxidase: Physiological significance of the redox reactions. -Journal of Plant Research 113: 301-309.

[186] Takeuchi, Y., Kubo, H., Kasahara, H., Sakaki, T. (1996): Adaptive alterations in the activities of scavengers of active oxygen in cucumber cotyledons irradiated with UV-B. -Journal of Plant Physiology 147: 589-592.

[187] Talor, R.M., Tobin, A.K., Bray, C.M. (1997): DNA Damage and Repair in Plants. -In: Lumsden, P.J. (ed.) Plants and UV-B Responses to Environmental Change, Cambridge University Press, Cambridge

[188] Tekchandani, S., Guruprasad, K.N. (1998): Modulation of a guaiacol peroxidase inhibitor by UV-B in cucumber cotyledons. -Plant Science 136: 131-137.

[189] Teramura, A.H. (1980): Effects of ultraviolet-B irradiances on soybean .1. importance of photosynthetically active radiation in evaluating ultraviolet-b irradiance effects on soybean and wheat growth. -Physiologia Plantarum 48: 333-339.

[190] Tevini, M., Braun, J., Fieser, G. (1991): The protective function of the epidermal layer of rye seedlings against ultraviolet-b radiation. -Photochemistry and Photobiology 53: 329-333.

[191] Tevini, M., Teramura, A.H. (1989): UV-B effects on terrestrial plants. -Photochemistry and Photobiology 50: 479-487.

[192] Ulm, R., Baumann, A., Oravecz, A., Mate, Z., Adam, E., Oakeley, E.J., Schafer, E., Nagy, F. (2004): Genome-wide analysis of gene expression reveals function of the bZIP transcription factor HY5 in the UV-B response of Arabidopsis. -Proceedings of the National Academy of Sciences of the United States of America 101: 1397-1402.

[193] Wang, C.X., Liu Y.L., Li, F.M., Wang, Z.J., Liu, X.G., Peng, A. (2000): Inhibition effect of rare earth nitrates on superoxide anion radical by pulse radiolysis. -Journal of the Chinese Rare Earth Society 18: 286-290.

[194] Wang, G.H., Chen, K., Chen, L.Z., Hu, C.X., Zhang, D.L., Liu, Y.D. (2008): The involvement of the antioxidant system in protection of desert cyanobacterium Nostoc $\mathrm{sp}$ against UV-B radiation and the effects of exogenous antioxidants. -Ecotoxicology and Environmental Safety 69: 150-157.

[195] Wang, X.Q., Ullah, H., Jones, A.M., Assmann, S.M. (2001): G protein regulation of ion channels and abscisic acid signaling in Arabidopsis guard cells. -Science 292: 2070-2072.

[196] Wang, Z.Y., Kenigsbuch, D., Sun, L., Harel, E., Ong, M.S., Tobin, E.M. (1997): A Myb-related transcription factor is involved in the phytochrome regulation of an Arabidopsis Lhcb gene. -Plant Cell 9: 491-507. 
[197] Wargent, J.J., Moore, J.P., Roland Ennos, A., Paul, N.D. (2009): Ultraviolet Radiation as a Limiting Factor in Leaf Expansion and Development. -Photochemistry and Photobiology 85: 279-286.

[198] Warren, J.M., Bassman, J.H., Fellman, J.K., Mattinson, D.S., Eigenbrode, S. (2003): Ultraviolet-B radiation alters phenolic salicylate and flavonoid composition of Populus trichocarpa leaves. -Tree Physiology 23: 527-535.

[199] Wefers, H., Sies, H. (1988): The protection by ascorbate and glutathione against microsomal lipid-peroxidation is dependent on vitamin E. -European Journal of Biochemistry 174: 353-357.

[200] Willekens, H., Vancamp, W., Vanmontagu, M., Inze, D., Langebartels, C., Sandermann, H. (1994): Ozone, sulfur-dioxide, and ultraviolet-B have similar effects on messenger-RNA accumulation of antioxidant genes in Nicotiana plumbaginifolia L. -Plant Physiology 106: 1007-1014.

[201] Winter, T.R., Rostas, M. (2008): Ambient ultraviolet radiation induces protective responses in soybean but does not attenuate indirect defense. -Environmental Pollution 155: 290-297.

[202] Wright, L.A., Murphy, T.M., Travis, R.L. (1981): The effect of ultraviolet-radiation on wheat root vesicles enriched in plasma membrane. -Photochemistry and Photobiology 33: 343-348.

[203] Xu, C.P., Natarajan, S., Sullivan, J.H. (2008a): Impact of solar ultraviolet-B radiation on the antioxidant defense system in soybean lines differing in flavonoid contents. -Environmental and Experimental Botany 63: 39-48.

[204] Xu, C.P., Sullivan, J.H., Garrett, W.M., Caperna, T.J., Natarajan, S. (2008b): Impact of solar Ultraviolet-B on the proteome in soybean lines differing in flavonoid contents. -Phytochemistry 69: 38-48.

[205] Yamashoji, S., Yoshida, H., Kajimoto, G. (1979): Photooxidation of linoleic acid by ultraviolet light and effect of superoxide anion quencher. -Food and Nutrition 43: 1249-1254.

[206] Yang, J.H., Chen, T., Wang, X. (2000): Effect of enhanced UVB radiation on endogenous ABA and free proline in wheat (Triticum asetivum L.). -Acta Ecologica Sinica 20: 39-42.

[207] Yang, Y.Q., Yao, Y., Xu, G., Li, C.Y. (2005): Growth and physiological responses to drought and elevated ultraviolet-B in two contrasting populations of Hippophae rhamnoides. -Physiologia Plantarum 124: 431-440.

[208] Yannarelli, G.G., Gallego, S.M., Tomaro, M.L. (2006a): Effect of UV-B radiation on the activity and isoforms of enzymes with peroxidase activity in sunflower cotyledons. -Environmental and Experimental Botany 56: 174-181.

[209] Yannarelli, G.G., Noriega, G.O., Batlle, A., Tomaro, M.L. (2006b): Heme oxygenase up-regulation in ultraviolet-B irradiated soybean plants involves reactive oxygen species. -Planta 224: 1154-1162.

[210] Yao, Y., Xuan, Z., Li, Y., He, Y., Korpelainen, H., Li, C. (2006): Effects of ultraviolet-B radiation on crop growth, development, yield and leaf pigment concentration of tartary buckwheat (Fagopyrum tataricum) under field conditions. -European Journal of Agronomy 25: 215-222.

[211] Zaffari, G.R., Peres, L.E.P., Kerbauy, G.B. (1998): Endogenous levels of cytokinins, indoleacetic acid, abscisic acid, and pigments in variegated somaclones of micropropagated banana leaves. -Journal of Plant Growth Regulation 17: 59-61.

[212] Zancan, S., Suglia, I., La Rocca, N., Ghisi, R. (2008): Effects of UV-B radiation on 
antioxidant parameters of iron-deficient barley plants. -Environmental and Experimental Botany 63: 71-79.

[213] Zhu, Y.Y., Nomura, T., Xu, Y.H., Zhang, Y.Y., Peng, Y., Mao, B.Z., Hanada, A., Zhou, H.C., Wang, R.X., Li, P.J., Zhu, X.D., Mander, L.N., Kamiya, Y., Yamaguchi, S., He, Z.H. (2006): Elongated uppermost internode encodes a cytochrome P450 monooxygenase that epoxidizes gibberellins in a novel deactivation reaction in rice. -Plant Cell 18: 442-456.

[214] Zu, Y.G., Pang, H.H., Yu, J.H., Li, D.W., Wei, X.X., Gao, Y.X., Tong, L. (2010): Responses in the morphology, physiology and biochemistry of Taxus chinensis var. mairei grown under supplementary UV-B radiation. -Journal of Photochemistry and Photobiology B-Biology 98: 152-158.

[215] Zu, Y.Q., Li, Y., Chen, H.Y., Chen, J.J. (2003): Intraspecific differences in physiological response of 20 soybean cultivars to enhanced ultraviolet-B radiation under field conditions. -Environmental and Experimental Botany 50: 87-97. 